\title{
Azorean freshwater invertebrates: Status, threats and biogeographic notes
}

\author{
Pedro Miguel Raposeiro ${ }^{1, *}$, Ana Mafalda Cruz ${ }^{1}$, Samantha Jane Hughes ${ }^{2}$ and Ana Cristina \\ Costa $^{1}$
}

${ }^{1}$ Research Centre in Biodiversity and Genetic Resources (CIBIO)-Açores and the Biology Department, University of Azores, Rua Mãe de Deus 13A, 9501-855 Ponta Delgada, Açores, Portugal.

${ }^{2}$ Centre for the Research and Technology of Agro-Environment and Biological Sciences, University of Trásos-Montes e Alto Douro, Apartado 1013, 5001-801 Vila Real, Portugal.

* Corresponding author: raposeiro@uac.pt

Received: 8/10/2010

Accepted: 6/5/2011

\begin{abstract}
Azorean freshwater invertebrates: Status, threats and biogeographic notes

This paper presents an updated catalogue of the freshwater invertebrates of the Azores archipelago and reviews the published records to account for the current taxonomic status and changes in the nomenclature of the listed taxa.

The number of freshwater invertebrate species that has been recorded in the Azores has risen sharply throughout the 20th century to 241 species based on field collections and the identification by several generations of local and foreign researchers. The freshwater fauna has been described as the following: (i) being "disharmonic", i.e., lacking taxa commonly found in continental freshwater systems such as the Plecoptera, and (ii) possessing a relatively high degree of endemism in selected groups. As expected, most recorded invertebrates are primarily of Palaearctic origin. However, endemic species make up $11 \%$ of the freshwater invertebrate fauna, which emphasises the unique character of Azorean freshwater habitats, the importance of conservation measures and the need to continue the study of these systems.
\end{abstract}

Key words: Azores, invertebrates, insular, freshwater systems, catalogue.

\section{RESUMEN}

\section{Invertebrados acuáticos de las Azores: Estado, amenazas y notas biogeográficas}

Este artículo presenta un catalogo actualizado de los invertebrados acuáticos presentes en el Archipiélago de las Azores. La revisión de los registros publicados de estos animales dulceacuícolas se ha realizado teniendo en cuenta el estado taxonómico actual y los cambios en las nomenclaturas de las taxones listados. De todas las maneras la lista no pretende ser un catalogo definitivo, dado que nuevos registros continúan apareciendo, en particular, aquellos que pertenecen a habitats poco estudiados, como es el caso de los sistemas acuáticos dulceacuícolas de las Azores.

El número de registros de especies de invertebrados de agua dulce en Azores ha sufrido un incremento importante a lo largo del siglo XX alcanzando 241 especies, que refleja los esfuerzos realizados en la recolección e identificación por parte de varias generaciones de investigadores. La fauna acuática es inarmónica faltando taxones comunes que si existen en los sistemas dulceacuícolas continentales, tal es el caso de los Plecoptera, y abundam los endemismos en otros grupos. La mayoría de invertebrados catalogados son primordialmente de origen Paleártico. Sin embargo, el porcentaje de especies endémicas es de 11 \% lo que enfatiza el carácter único de estas especies de Las Azores, la importancia de su conservación y la necesidad de proseguir con un trabajo continuado.

Palabras clave: Azores, invertebrados, insular, sistemas dulceacuícolas, catálogo. 


\section{INTRODUCTION}

The presence of freshwater invertebrates in oceanic islands has always raised questions concerning dispersal, colonization and evolution; even their absence is proclaimed as evidence about the mechanisms governing those processes (e.g. Bass, 2003; Covich, 2006).

During the latter part of the nineteenth century, several naturalists visited the Azores. Guerne published the first works on the Azorean freshwater fauna (Guerne, 1887a,b,c; 1888a,b) following visits to six islands (Corvo, Flores, Faial, Pico, Graciosa and São Miguel) between 1887 and 1889. In the same year Barrois published several papers, including the first records of water mites (Barrois, 1888a) and additions for Ostracods, Cladocera, Branchiopods (Barrois, 1888b) and Rotifers (Barrois, 1888c).

Chopard and Méquignon (1930) made collections on the Azores subsequently publishing several papers that included the first records of Odonata (Navás, 1933) and several additions to the Coleopterous fauna (Méquignon, 1942a, b). Collections made in 1938 by Frey, Stora and Cedercreutz provided additions to the Azorean Diptera (Frey, 1945; Stora, 1945; Cedercreutz, 1941). Subsequently, Freeman (1959), Marcus \& Marcus (1959), Sciacchitano (1961, 1964a,b), Carlsson, (1963), Nielsen (1963), Nybom (1965) reported more findings based on Brinck and Dahl's findings following the Lund University Expedition to Madeira and the Azores in 1957. Svensson $(1970,1977)$ published on the Coleptera (Dytiscidae and Gyrinidae) while Backhuys (1975), contributed to the Azorean freshwater fauna in his revision of the Azorean land and fresh-water malacofauna. The local naturalist Dalberto Pombo has performed several collections on different islands with a specific concentration on Santa Maria. Defaye \& Dussart (1991) recorded several species of Copepoda after studying material that was collected during the Biaçores expedition in 1971 by Monod. On his trip to São Miguel, Pico, Terceira and Flores, Green (1992) studied and published on zooplankton diversity. Medeiros et al. (1996) studied zooplankton diversity again in a commissioned work for the Azorean Government.
Murray et al., (2004) provided several new additions and a checklist of chironomids. Borges $e t$ $a l$., (2005), published the first list of Azorean terrestrial fauna e flora, later updating and expanding upon this first publication (Borges et al., 2010).

The implementation of the Water Frame Directive [European Parliament \& The Council of the European (2000); WFD] has increased emphasis on the importance of regional freshwater studies and the characterization of biological elements. Studies have confirmed the presence of species described in past publications and found new records for the Archipelago (e.g. Malhão et al., 2007; Raposeiro et al., 2007; Gonçalves et al., 2008; Raposeiro \& Costa, 2009; Raposeiro et al., 2009a,b). The literature has clearly shown that some groups have been better characterised than others. It is, however, unclear if the relative proportion of available publications for each group reflects its relative species richness. There can be little doubt, for example, that some groups are poorly known because of their small size, complicated taxonomy (e.g., Acari, Oligochaeta) or sampling difficulty (e.g. deep lakes, wetlands).

The current study presents an updated catalogue of the Azorean freshwater invertebrate fauna. An extensive review of all published records was performed and accounted for the current taxonomic status and any changes in the nomenclature. This list provided an updated inventory, which will require regular updates as new records continue to appear, especially from poorly studied habitats such as the freshwater bodies. The list is an useful resource for research and management and provides information on species distribution within the archipelago that will benefit conservation measures and future research on biogeographical and macroecological hypotheses using island systems.

\section{METHODS}

\section{Study Area}

The archipelago of the Azores is comprised of nine islands and several islets that can be divided into three groups (Fig. 1). São Miguel and Corvo 


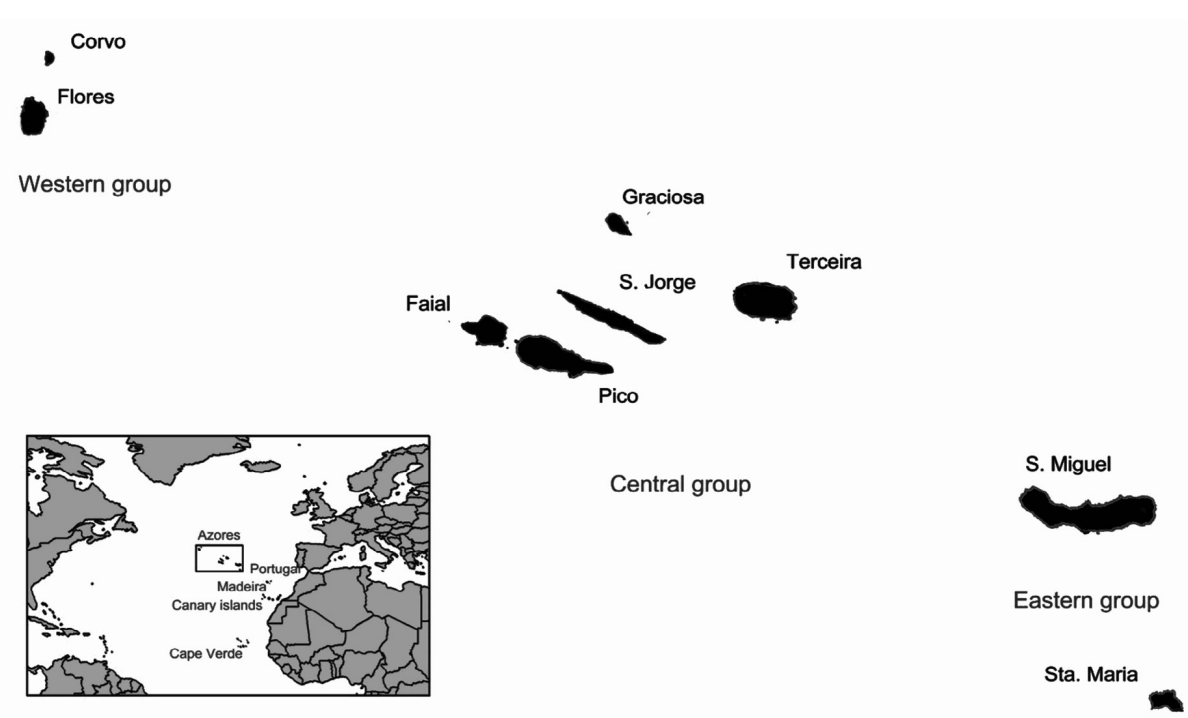

Figure 1. The location of the Azorean archipelago in the North Atlantic Ocean and the nine islands of the Azores. Localización del Archipiélago de las Azores en el Océano Atlántico Norte y de las nueve islas de Las Azores.

are the largest and smallest islands, respectively, with total areas of $745 \mathrm{~km}^{2}$ and $17 \mathrm{~km}^{2}$, respectively. The central group (Terceira, Faial, Graciosa, Pico and São Jorge) is situated $220 \mathrm{~km}$ from the western group (Flores and Corvo) and $136 \mathrm{~km}$ from the eastern group (São Miguel and Santa Maria). The archipelago spans $615 \mathrm{~km}$ and is located approximately $1300 \mathrm{~km}$ west of Portugal, $1600 \mathrm{~km}$ east of North America and $800 \mathrm{~km}$ northwest of Madeira. From a biogeographical perspective, the Azores archipelago is often grouped with the Cape Verdes, Canary Islands, Salvage Islands and Madeira in the Macaronesian region.

The Azorean climate is oceanic and temperate (Bettencourt, 1979). Wind patterns differ among the islands with south- and southwest-prevailing winds in the western and central groups and north- and northeastern-prevailing winds predominating in the eastern group (Porteiro, 2000). Geologically, the Azores archipelago forms a volcanic plateau that is 20-36 million years old. The youngest rocks are located on Pico island and are approximately 0.250 million years old, whereas the oldest rocks, which are located on the island of Santa Maria, emerged 8.12 million years ago (Borges \& Brown, 1999; Quartau, 2007).

Azorean lotic systems are characteristically situated in small, short and steep catchments; the streams are short, steep and deeply incised. Permanent streams, fed by lakes or spring waters, exist only in Santa Maria, São Miguel, São Jorge, Faial and Flores islands (DROTRH/INAG, 2001). The Azores are particularly rich in lentic habitats with over 88 lakes (Porteiro, 2000), located on São Miguel, Terceira, Pico, Flores and Corvo. Lentic systems tend to be flooded volcanic craters and caldeiras (Azevedo, 1998; Nunes, 1999).

\section{Checklist of the Azorean freshwater invertebrates}

The taxonomic list was based on the published literature (Annex I) and some unpublished data, which was gathered during routine work that was performed for the regional government on the ecological quality of superficial waters over the last six years (eastern and western groups as well as in Faial and Pico in the central group). The nomenclature that was used for species was consistent with the recent list of European terrestrial species in Project FAUNA EUROPAEA (http://faunaeur.org).

All species of doubtful identification (e.g., misidentification, presence of species has never confirmed) were removed from the main list and were included in Annex III. 
Codes describing species distribution across the nine Azorean islands were used as follows: COR - Corvo; FLO - Flores; FAI - Faial; PIC Pico; GRA - Graciosa; SJG - São Jorge; TER Terceira; SMG - São Miguel and SMR - Santa Maria. If no information was available on the island, the material was collected using the designation AZ for the Azorean archipelago. Zoogeographical comments are provided in the list using the following symbols: COS - Cosmopolitan or almost cosmopolitan; HOL - Holartic; PAL Palaeartic; NEA - Neartic; ETH - Ethiopian; END - Endemic and MAC - Macaronesian.

\section{RESULTS}

A total of 241 species, belonging to 76 families and 164 genera, have been found in the bibliography and in unpublished data. Their name can be seen in the electronic version of this journal (www.limnetica.net/internet/index.html). The number of recorded species for each island is now 189 species for São Miguel, 111 species for Flores, 100 species for Terceira, 87 species for Faial, 83 species for Pico, 82 species for Santa Maria, 60 species for São Jorge and 29 species each for Graciosa and Corvo. A summary of the freshwater invertebrates groups found in the Azores and on each of the nine islands is given in Table 1. The Arthropoda represent the most diverse Azorean Phylum, comprising approximately $89.7 \%$ of the taxa. The Diptera is the richest group (96 taxa) followed by Crustacea (92 taxa). The Hydracarina (Sperchon brevirostris) and Ephemeroptera (Cloeon dipterum) are represented by single species. The Chironomidae is the most diverse family with 43 species, 3 of which are endemic to Macaronesia. The highest number of endemic taxa occurs in the Diptera (16 taxa, $6.69 \%$ of the species are endemic). The Empididae and Ephydridae both have 4 endemic species, followed by the Dolichopodidae with 3 endemic species; the single species of Simuliidae recorded from the Azores is also endemic.

The Azorean freshwater invertebrate fauna is predominantly Palaearctic $(35 \%)$ in origin (Fig. 2) with the majority of the taxa originating from Europe. Thirty percent of the taxa occur across several biogeographical regions. For example most of the Azorean Oligochaeta and zooplankton species have cosmopolitan distribution. Holartic taxa $(20 \%)$ are also well represented in Azores. Azorean endemic species comprise $11 \%$ of the macroinvertebrate fauna; Macaronesian endemics comprise $3 \%$ of the Azorean invertebrate fauna. Macaronesian endemics Cardiocladius freyi, Dicranomyia michaeli, Dicranomyia vicina, Clogmia albipunctata, Hydroptila fortunata occur in the Azores, Madeira and Canary Islands while Diamesa alata and Microsepta freyi are known from the Azores and Madeira.

Table 1. Diversity of the main groups for each island. Diversidad de los grupos principales para cada isla.

\begin{tabular}{|c|c|c|c|c|c|c|c|c|c|c|}
\hline \multirow[b]{2}{*}{ Groups } & \multicolumn{3}{|c|}{ Western } & \multicolumn{5}{|c|}{ Central } & \multicolumn{2}{|c|}{ Eastern } \\
\hline & $\mathrm{AZ}$ & COR & FLO & FAI & PIC & GRA & SJG & TER & SMG & SMR \\
\hline Platyhelminthes & 0 & 0 & 2 & 0 & 0 & 0 & 0 & 0 & 6 & 2 \\
\hline Mollusca & 0 & 1 & 1 & 1 & 1 & 1 & 0 & 3 & 5 & 4 \\
\hline Annelida & 0 & 0 & 2 & 6 & 1 & 2 & 0 & 2 & 13 & 4 \\
\hline Acari & 0 & 0 & 1 & 1 & 0 & 0 & 1 & 1 & 1 & 1 \\
\hline Crustacea & 0 & 3 & 31 & 18 & 28 & 5 & 3 & 19 & 64 & 19 \\
\hline Ephemeroptera & 0 & 0 & 0 & 1 & 1 & 1 & 1 & 1 & 1 & 1 \\
\hline Odonata & 0 & 4 & 4 & 4 & 4 & 2 & 4 & 4 & 4 & 4 \\
\hline Hemiptera & 2 & 0 & 2 & 1 & 2 & 0 & 0 & 3 & 5 & 2 \\
\hline Coleoptera & 0 & 2 & 8 & 5 & 6 & 2 & 4 & 6 & 8 & 10 \\
\hline Diptera & 2 & 17 & 57 & 48 & 37 & 16 & 45 & 59 & 79 & 34 \\
\hline Trichoptera & 1 & 2 & 3 & 2 & 3 & 0 & 2 & 2 & 3 & 1 \\
\hline Total & 5 & 29 & 111 & 87 & 83 & 29 & 60 & 100 & 189 & 82 \\
\hline
\end{tabular}




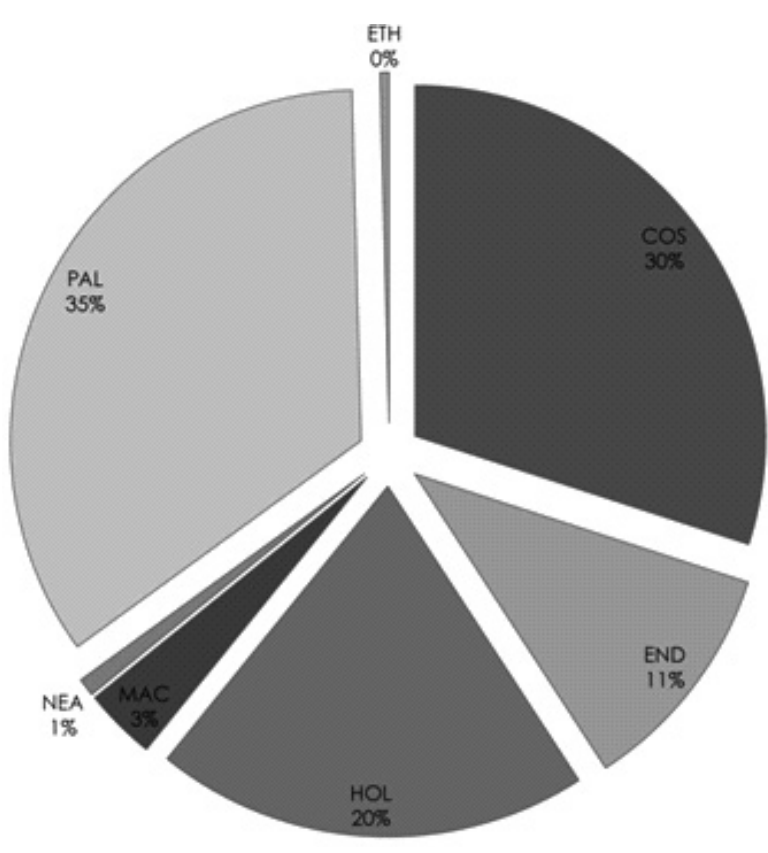

Figure 2. Biogeographic origin of Azorean freshwater invertebrates. Percentages of each origin are shown. PAL-Palaearctic; ETH-Ethiopian; COS-Cosmopolitan; ENDEndemic; HOL-Holarctic; MAC-Macaronesian; NEA-Neartic. Origen biogeográfico de los invertebrados acuáticos de Las Azores. Porcentajes para cada región biogeográfica considerada. PAL-Paleártico; ETH-Etíope; COS-Cosmopolita; END-Endémico; HOL-Holártico; MAC-Macaronésica; NEANeártica.

\section{DISCUSSION}

The number of freshwater invertebrate species recorded from the Azores has risen sharply throughout the 20th century, and currently stands at 241 species. This increase is the result of increased sampling efforts and the identification of material by several generations of local and foreign researchers. For example, from the 1880's the 1960's, an average of 19 new records were added per decade. However, the number of new records has risen to an average of 24 per decade over the last 50 years. However, the knowledge of the actual diversity and complexity of the Azorean freshwater fauna is relatively incipient.

With the implementation of the WFD in 2000, studies characterizing Azorean freshwater ecosystems have increased. As a result the number of new records has increased by $11.98 \%$ in the last decade. A summary of the freshwater invertebrates groups found in the Azores and on each of the nine islands is present in Table 1.

The quantity of freshwater available in the islands is vital for species diversity. For example, São Miguel, Flores and Terceira islands have several lakes, permanent streams, wetlands and peat bogs islands, providing a diverse array of freshwater habitats and favorable colonization conditions for colonizing species. In contrast, permanent streams are absent in Graciosa, Corvo and Pico. In addition, lakes are absent in Santa Maria, Graciosa and Faial. The low macroinvertebrate richness found in Azores archipelago is typical of truly oceanic islands. Their remoteness strongly limits the dispersal of colonisers and the evolution of trophically complex freshwater habitats (Covich, 2006; 2009). The Azorean freshwater fauna is "disharmonic", because it lacks the taxa that are common to continental freshwater systems such as the Plecoptera and with a relatively high degree of endemism in others groups such as Trichoptera and Coleoptera (Gonçalves et al., 2008; Raposeiro \& Costa, 2009; Raposeiro et al. 2009a). A reduced number of groups are present. Each group exhibits low levels of diversity (e.g., Ephemeroptera-Cloeon dipterum). Groups such as the Chironomidae and Trichoptera predominate, whereas others are poorly represented or absent. Similar to other Macaronesian islands, Plecoptera are absent from the Azores (MadeiraHughes, 2006; Borges et al., 2008; CanariasMalmqvist et al., 1993; Izquierdo et al., 2001). The absence of key taxa such as stoneflies is caused by the low dispersal capacity of the adults and the highly specific ecological needs of the larvae (Fochetti \& Tierno de Figueroa, 2008).

Numerous species are adapted for colonization of insular freshwater systems by using different mechanisms of active and passive dispersal (Bilton et al., 2001; Covich, 2006; 2009). Passive dispersal via an external agent (e.g. strong winds storms; attachment to rafts of floating wood and pumice) usually results in long distance transoceanic dispersal (Thiel \& Gutow, 2005; Covich, 2006; 2009). Dormant individuals (e.g. Zooplankton) and egg masses (e.g. Diptera and Gastropoda) can also be carried by other larger 
organisms (e.g. Bilton et al., 2001; Figuerola \& Green, 2002; Green \& Figuerola, 2005). In some Azorean species, like Ischnura hastate (Say) (Odonata: Coenagrionidae), a parthenogenetic species (Rivera et al., 2005), a single individual can disperse and colonize available habitats.

Active dispersal, which involves the selfgenerated movement by individuals (swimming, crawling or flying), is more effective over shorter distances. This is important for "stepping stone" colonisation (Whittaker \& Fernandez-Palacios, 2007) between islands. As result of these barriers and biogeographical "filters", the Azorean freshwater fauna is largely represented by insects with taxa that occupy a wide number of niches due to the relative absence of competitors for local resources. A similar situation pertains to Tenerife (Malmqvist et al., 1993) and Madeira (Hughes, 2003).

The freshwater fauna of the Azores is impoverished when compared to other Macaronesian archipelagos (Madeira and the Canary islands). For example the percentage of endemic species in Azores $(11 \%)$ is lower than Madeira archipelago (25.5\% [Hughes, 2003]), and Canary Islands with $(28 \%)$ in Gran Canaria (Nilsson et al., 1998) and $39 \%$ in Tenerife (Malmqvist et al., 1995).

The Madeira archipelago is three times smaller $\left(810 \mathrm{~km}^{2}\right)$, older (Porto Santo-14 million years old) and closer to the mainland $(800 \mathrm{~km})$. The Canary Islands is three times larger $\left(7447 \mathrm{~km}^{2}\right)$, older (Fuerteventura-20.6 million years old) and closer to the mainland $(85 \mathrm{~km})$. Given the isolation and geological youth of the Azores, the ancient freshwater colonisers had to travel over a significant distance from the Madeiran archipelago or, in most cases, from the European mainland $(1200 \mathrm{~km})$, over a relatively short geological period (Santa Maria-8.12 million years old).

The Coleoptera and Trichoptera have the highest levels of endemism for the region of Macaronesia (Table 2). The level of estimated endemism in the Azores (11\%) highlights the considerable conservation value of the invertebrate freshwater fauna. Extensive habitat destruction resulting from human intervention has affected the Azorean freshwater systems after the human colonisation of the islands. Contemporary legislation such as the Habitats Directive and the
Table 2. Levels of endemicity (\%) for selected freshwater insect orders in the Macaronesian region. Data from Gran Canaria (Nilson et al., 1998), Tenerife (Malmqvist et al., 1995) and Madeira (Hughes et al., 1998; Hughes 2003) are shown. Niveles de endemicidad (\%) para órdenes de insectos acuáticos en distintas islas macaronésicas. Datos de Gran Canaria (Nilson et al., 1998), Tenerife (Malmqvist et al., 1995) y Madeira (Hughes et al., 1998; Hughes 2003).

\begin{tabular}{lcccc}
\hline Taxonomic group & Gran Canaria & Tenerife & Madeira & Azores \\
\hline Ephemeroptera & 40 & 33 & 0 & 0 \\
Odonata & 10 & 10 & 0 & 0 \\
Hemiptera & 13 & 17 & 0 & 0 \\
Coleoptera & 32 & 32 & 48 & 25 \\
Trichoptera & 30 & 64 & 67 & 33 \\
Diptera & 29 & 49 & 18 & 17 \\
\hline
\end{tabular}

WFD encourage a proactive approach concerning the sustainable management and the protection of the natural environment and resources. As a consequence, Azorean authorities have established protected areas which are strategically important for maintaining freshwater biodiversity, as changes land use in the catchment strongly influence the ecological quality of freshwater systems (Cymbron et al., 2005; Gonçalves et al., 2008 Hughes et al., 2007).

Like all insular systems, Azorean freshwater systems are potentially highly vulnerable to invasive species due to the low levels of diversity (and therefore competitors) and the relative availability of ecological niches. Procambarus clarkii and Ferrisia fragilaris (natives from America) have been introduced to Azorean freshwaters by aquarists. The existing conditions have allowed them to spread quickly from original site where they were introduced. Another example is the accidental introduction of Lymnaea truncatula in São Miguel via sheep imported from mainland Portugal. Lymnaea truncatula is an intermediate host for the trematode Fasciola hepat$i c a$, which causes fasciolosis. In Azores it is restricted to the eastern half of the island of São Miguel and to Santa Maria. More recently, Raposeiro et al., 2009b reported the presence of Branchiura sowerbyi (Oligochaeta: Tubificidae) in Azores. The establishment and consequences of introduced species has been subject to discussion in many studies (e.g. Mooney \& Hobbs 2000); however we are still not able to predict outcome of the introduction of particular species, 
as well as the impact of invasions in general to specific ecosystem, although insular systems are historically highly vulnerable.

Long-term, in depth studies on the temporaryspatial distribution patterns, trophic complexity and patterns of voltinism of Azorean freshwater biological elements are essential for improving knowledge and the development of typologically appropriate monitoring and conservation programmes and measure for regional stakeholders. Such studies imply the active collaboration between politicians, scientists and the local population.

\section{ACKNOWLEDGEMENTS}

Part of this study was financed by the Fundação para a Ciência e Tecnologia (FCT-SFRH/ BD/28798/2006). We thank Paulo Borges and Enésima Mendonça from CITA-A for their collaboration. We thank Dr. Luz Paramio Martín for the revision of the Spanish abstract. We thank 2 anonymous referees for comments that improved earlier versions of this paper.

\section{REFERENCES}

AZEVEDO, J. M. M. 1998. Geologia e hidrologia da Ilha das Flores (Açores- Portugal). Dissertação para a obtenção do grau de Doutor em Geologia. Departamento de Ciências da Terra, Universidade de Coimbra, Coimbra. 403 pp.

BACKHUYS, W. 1975. Zoogeography and Taxonomy of the Land and Freshwater Molluscs of the Azores. Backhuys \& Meesters, Amsterdam. 350 pp.

BARROIS, T. D. 1888a. Matériaux pour servir a l'étude de la faune des eaux douce des Açores. I. Hydrachnides. Imprimérie Le Bigot Frères, Lille. $16 \mathrm{pp}$.

BARROIS, T. D. 1888b. Matériaux pour servir a l'étude de la faune des eaux douce des Açores. II. Rotifères. III. Protozoaires. Imprimérie Le Bigot Frères, Lille. 12 pp.

BARROIS, T. D. 1888c. Matériaux pour servir a l'étude de la faune des eaux douce des Açores. IV. Crustacès. Imprimérie Le Bigot Frères, Lille. 20 pp.

BASS, D. 2003. A Comparison of Freshwater Macroinvertebrate Communities on Small Caribbean
Islands. BioScience, 53: 1094-1100.

BETTENCOURT, M. L. 1979. O clima dos Açores como recurso natural na aplicação especialmente em agricultura e indústria do turismo. Instituto Nacional de Meteorologia e Geofísica, Lisboa. $63 \mathrm{pp}$.

BILTON, D. T., J. R. FREELAND \& B. OKAMURA. 2001. Dispersal in freshwater invertebrates. Annu. Rev. Ecol. Syst., 32: 159-181.

BORGES, P. A. V., C. ABREU, A. M. F. AGUIAR, P. CARVALHO, R. JARDIM, I. MELO, P. OLIVEIRA, C. SÉRGIO, A. R. M. SERRANO \& P. VIEIRA. 2008. A list of the terrestrial fungi, flora and fauna of Madeira and Selvagens archipelagos. Direcção Regional do Ambiente da Madeira e Universidade dos Açores, Funchal and Angra do Heroísmo. 440 pp.

BORGES, P. A. V. \& V. K. BROWN. 1999. Effect of island geological age on the arthropod species richness of Azorean pastures. Biol. J. Linn. Soc., 66: 373-410.

BORGES, P. A. V., A. COSTA, R. CUNHA, R. GABRIEL, V. GONÇALVES, A. M. FRIAS MARTINS, I. MELO, M. PARENTE, P. RAPOSEIRO, P. RODRIGUES, R. S. SANTOS, L. SILVA \& V. VIEIRA. 2010. A list of the terrestrial and marine biota from the Azores. Princípia, Cascais. 432 pp.

BORGES, P. A. V., R. CUNHA, R. GABRIEL, A. F. MARTINS, L. SILVA \& V. VIEIRA. 2005. A list of terrestrial fauna (Mollusca and Arthropoda) and Flora (Bryophyta, Pteridophyta and Spermatophyta) from the Azores. Direcção Regional do Ambiente and Universidade dos Açores, Angra do Heroísmo and Ponta Delgada. 317 pp.

BOUDOT, J. P., V. J. KALKMAN, M. AZPILICUETA AMORÍN, T. BOGDANOVIC, A. CORDERO RIVERA, G. DEGABRIELE, J.-L. DOMMANGET, S. FERREIRA, B. GARRIGÓS, M. JOVIC, M. KOTARAC, W. LOPAU, M. MARINOV, N. MIHOKOVIC, E. RISERVATO, B. SAMRAUOI \& W. SCHNEIDER. 2009. Atlas of the Odonata of the Mediterranean and North Africa. Libellula, Supplement 9: 1-256.

CARLSSON, G. 1963. Black flies, Simuliidae (Diptera, Nematocera) from Madeira and the Azores. Boletim do Museu Municipal do Funchal, 17: 8594.

CEDERCREUTZ, C. 1941. Beitrag zur kenntnis der süsswasseralgen auf den Azoren. Societas Scientiarum Fennica, Commentationes Biologicae, 8: 136. 
COVICH, A. P. 2006. Dispersal-limited biodiversity of tropical insular streams. Polish Journal of Ecology, 54: 523-547.

COVICH, A. P. 2009. Freshwater ecology. In: Encyclopedia of islands. R. G. Gillespie \& D. A. Clague (eds.): 343-347. University of California Press, Berkeley.

CYMBRON, R., D. PACHECO, V. GONÇALVES, C. CABRAL, J. V. CRUZ, P. RAPOSEIRO, A. COSTA, H. MARQUES, M. DOMINGOS, J. C. NUNES, R. COUTINHO \& L. CABILDO DE. 2005. Monitorização da qualidade das águas interiores das ilhas de Santa Maria e São Miguel da Região Autónoma dos Açores. In: Técnicas e métodos para a gestão sustentável da água na Macaronésia. Canarias, ITCITD (ed.): 295-334. Islas Canarias.

DEFAYE, D. \& B. DUSSART. 1991. Sur les Crustecés des Açores. Ann. Limnol.-Int. J. Lim., 27: 119132.

DROTRH/INAG. 2001. Plano Regional da Água. Relatório Técnico. Versão para Consulta Pública. Direcção Regional Ordenamento do Território e Recursos Hídricos-Instituto Nacional da Água, Ponta Delgada. 414 pp.

EUROPEAN, P. \& U. THE COUNCIL OF THE EUROPEAN. 2000. Directive 2000/60/EC of the European Parliament and of the Council establishing a framework for the Community action in the field of water policy. OJEC, 327: 1-72.

FIGUEROLA, J. \& A. J. GREEN. 2002. Dispersal of aquatic organisms by waterbirds: A review of past research and priorities for future studies Freshwater Biology, 47.

FOCHETTI, R. \& J. M. TIERNO DE FIGUEROA. 2008. Global diversity of stoneflies (Plecoptera; Insecta) in freshwater. In: Freshwater Animal Diversity Assessment. Balian, E. V., C. Lévêque, H. Segers \& K. Martens (eds.): 365-377. Springer Netherlands.

FREEMAN, P. 1959. Chironomidae (Diptera, Nematocera) from Azores and Madeira. Boletim do Museu Municipal do Funchal, 12: 5-15.

FREY, R. 1945. Tiergeographische Studieb uber die Dipteren-fauna der Azorean. I. Verzeichnis der bisher von den Azoren bekannten Dipteren. Societas Scientiarum Fennica. Commentationes Biologicae, VIII: 1-114.

GONÇALVES, V., P. RAPOSEIRO, A. C. COSTA, H. MARQUES, V. MALHÃO, J. MICAEL \& A. CUNHA. 2008. Caracterização Ecológica das
Massas de Água Interiores das Ilhas de São Miguel e Santa Maria da Região Autónoma dos Açores. CCPA, Departamento de Biologia, Universidade dos Açores, Ponta Delgada: 117 pp.

GONÇALVES, V., P. RAPOSEIRO \& A. C. COSTA. 2008. Benthic diatoms and macroinvertebrates in the assessment of the ecological status of Azorean streams. Limnetica, 27: 317-328.

GREEN, A. J. \& J. FIGUEROLA. 2005. Recent advances in the study of long-distance dispersal of aquatic invertebrates via birds. Diversity and Distributions, 11: 149-156.

GREEN, J. 1992. Island biogeography, diversity and dominance of zooplankton in crater lakes on Azores. Biol. J. Linn. Soc., 46: 189-205.

GUERNE, M. J. 1887a. Sur la faune des îles du Fayal et dee San Miguel (Açores). Comptes Rendus Hebdomadaires des Séances de l'Academie des Sciences, 105: 764-767.

GUERNE, M. J. 1887b. La faune des eaux douce des Açores et le transport des animaux a grande distance par l'intermédiaire des oiseaux. Du Comptes Rendu de la Société de Biologie, 8: 580-584.

GUERNE, M. J. 1887c. Notes sur la faune des Açores. Le Naturaliste, 9: 194-195.

GUERNE, M. J. 1888a. Sur les lacs de l'île Sam Miguel (Açores). Du Compte Rendu des Séances de la Commission Centrale, 13.

GUERNE, M. J. 1888b. Excursions zoologiques dans les iles de Fayal et de San Miguel (Açores). In: Campagnes scientifiques du Yacht Monégasque L. Hirondelle: 39-73. Gauthier-Villars et Fils, Imprimeurs-Liraires, Paris. 111 pp.

HUGHES, S. J. 2003. A study of the freshwater macroinvertebrate fauna of Madeira and their application in a regional ecological monitoring system. PhD thesis. University of London, UK. 328 pp.

HUGHES, S. J. 2006. Temporal and spatial distribution patterns of larval Trichoptera in Madeiran streams. Hydrobiologia, 553: 27-41.

HUGHES, S. J., M. T. FURSE, J. H. BLACKBURN \& P. H. LANGTON. 1998. A checklist of Madeiran freshwater macroinvertebrates. Bol. Mus. Mun. Funchal, 50: 5-41.

HUGHES, S. J., T. FERREIRA \& R. V. CORTES. 2007. Hierarchical spatial patterns and drivers of change in benthic macroinvertebrate communities in an intermittent Mediterranean river. Aquatic Conservation: Marine and Freshwater Ecosystems, 18: 742-760. 
IZQUIERDO, I., J. L. MARTÍN, N. ZURITA \& M. ARECHAVALETA. 2001. Lista de especies silvestres de Canarias (hongos, plantas y animales terrestres) 2001. Consejería de Política Territorial y Medio Ambiente Gobierno de Canarias, Islas Canarias. 437 pp.

MALHÃO, V., P. RAPOSEIRO \& A. C. COSTA. 2007. The Family Dugesiidae: New records for the Azorean Archipelago. Limnetica, 26: 121-130.

MALMQVIST, B., A. N. NILSSON, M. BAEZ, P. D. ARMITAGE \& J. BLACKBURN. 1993. Stream macroinvertebrate communities in the island of Tenerife. Arch. Hydrobiol., 128: 209-235.

MALMQVIST, B., A. N. NILSSON \& M. BAEZ. 1995. Tenerife's freshwater macroinvertebrates: status and threats (Canary Islands, Spain). Aquat. Conserv.: Mar. Freshwat. Ecosyst., 5: 1-24.

MARCUS, E. \& E. MARCUS. 1959. Turbellaria from Madeira and the Azores. Boletim do Museu Municipal do Funchal, XII: 15-42.

MEDEIROS, J., M. MACEDO, M. CABRAL, M. DOMINGOS, A. TAVARES, J. TAVARES, F. SANTANA, A. RODRIGUES, I. PERES, M. SANTOS, A. XAVIER \& M. JOSÉ. 1996. Análise das Águas das Lagoas da Região Autónoma dos Açores. INOVA, Ponta Delgada. 577 pp.

MÉQUIGNON, A. 1942a. Voyage de MM. L. Chopard et A. Méquignon aux Açores (Août-Septembre 1930). XIII Diagnoses de Coléoptères nouveaux. Bulletin de la Société Entomologique de France, 47: 9-11.

MÉQUIGNON, A. 1942b. Voyage de MM. L. Chopard et A. Méquignon aux Açores (Août-Septembre 1930). XIV. Catalogue des Coléoptéres nouveaux. Bulletin de la Société Entomologique de France, 47: 1-66.

MOONEY, H. A. \& R. J. HOBBS. 2000. Invasive species in a changing world. Island Press, Washington, D.C., USA. 357 pp.

MORELET, A. 1860. Notice sur L'Histoire Naturelle dês Açores. J. B. Bailière et Fils, Paris. 214 pp.

MURRAY, D. A., S. J. HUGHES, M. T. FURSE \& W. A. MURRAY. 2004. New records of Chironomidae (Diptera: Insecta) from the Azores, Macaronesia. Ann. Limnol.-Int. J. Lim., 40: 33-42.

NAVÁS, L. 1933. Voyage de MM. L. Chopard et A. Méquignon aux Açores (Août-September 1930). III: Néuroptères et Pseudo Néuroptéres. Annales de la Société Entomologique de France, 102: 19-24.
NIELSEN, P. 1963. Nematocera polyneura (Diptera) from Azores and Madeira. Boletim do Museu Municipal de Funchal, 17: 79-84.

NILSSON, A. N., B. MALMQVIST, M. BAEZ, J. H. BLACKBURN \& P. D. ARMITAGE. 1998. Stream insects and gastropods in the island of Gran Canaria (Spain). Ann. Limnol., 34: 413-435.

NUNES, J. C. 1999. A actividade vulcânica na Ilha do Pico do Plistocénio Superior ao Holocénio: mecanismo eruptivo e hazard vulcânico. Dissertação para a obtenção do grau de Doutor em Geologia. Departamento de Geociências, Universidade dos Açores, Ponta Delgada: 357 pp.

NYBOM, O. 1965. Trichoptera from Madeira an the Azores. Boletim do Museu Municipal de Funchal, 19: 88-94.

PORTEIRO, J. 2000. Lagoas dos Açores: elementos de suporte ao planeamento integrado. Dissertação para a obtenção do grau de Doutor em Geografia. Departamento de Biologia, Universidade dos Açores, Ponta Delgada. 344 pp.

QUARTAU, R. M. 2007. The insular shelf of Faial: Morphological and sedimentary evolution. Universidade de Aveiro, Aveiro. 301 pp.

RAPOSEIRO, P. M. \& A. C. COSTA. 2009. Benthic macroinvertebrate based indices for assessing the ecological status of freshwaters on oceanic islands. Arquipelago-Life and Marine Sciences, 26: 15-24.

RAPOSEIRO, P., A. COSTA \& A. F. MARTINS, 2007. Freshwater mollusks of the Azores: a reappraisal. World Congress of Malacology. Antwerp, Belgium: 175-176.

RAPOSEIRO, P., S. J. HUGHES \& A. C. COSTA. 2009a. Chironomidae (Diptera: Insecta) in oceanic islands: New records for the Azores and biogeographic notes. Ann. Limnol.-Int. J. Lim., 45: 59-67.

RAPOSEIRO, P. M., J. C. RAMOS \& A. C. COSTA. 2009b. First record of Branchiura sowerbyi Beddard, 1892 (Oligochaeta: Tubificidae) in Azores. Aquatic Invasions, 4: 487-490.

RIVERA, A. C., M. O. L. CARBALLA, C. UTZERI \& V. VIEIRA. 2005. Parthenogenetic Ischnura hastata widespread in the Azores (Zygoptera: Coenagrionidae). Odonatologica, 34: 1-9.

SCIACCHITANO, I. 1961. Hirudinees des Acores et de Madere. Boletim do Museu Municipal do Funchal, 14: 5-6.

SCIACCHITANO, I. 1964a. Hirudinées des Açores. Boletim do Museu Municipal do Funchal, XVIII: 121-122. 
SCIACCHITANO, I. 1964b. Oligochaeta des Açores. Boletim do Museu Municipal do Funchal, 18: 123128.

STORA, R. 1945. Chironomidae. In: Tiergeographische Studien über die Dipterenfauna der Azoren. I Verzeichnes der bisher von der Azoren bekannten Dipteren. Frey, R. (ed.): 1-114. Societas Scientarum Fennica. Commentations Biologicae.

SVENSSON, B. 1970. Dryopidae (Coleoptera) from the Azores and Madeira. Boletim do Museu Municipal do Funchal, 25: 44-48.
SVENSSON, B. 1977. Dysticidae and Gyrinidae (Coleoptera) from Azores and Madeira. Boletim do Museu Municipal do Funchal, 31: 87-99.

THIEL, M. \& L. GUTOW. 2005. The ecology of rafting in the marine environment. II. The rafting of organisms and community. Oceanography and $M a-$ rine Biology, 43: 279-418.

WHITTAKER, R. J. \& J. M. FERNÁNDEZ-PALACIOS. 2007. Island Biogeography. Ecology, Evolution, and Conservation. Oxford University Press, Oxford: $401 \mathrm{pp}$. 